\title{
Risk factors threatening health care facilities in disasters and emergencies
}

Behrad Pourmohammadi

Semnan University of Medical Sciences and Health Services

Ahad Heydari

Tehran University of Medical Sciences

Farin Fatemi ( $\nabla$ f-fatemi@alumnus.tums.ac.ir)

Semnan University of Medical Sciences

Ali Modarresi

Semnan University of Medical Sciences and Health Services

\section{Research article}

Keywords: Risk factor, Health Care Facilities, Disaster, Emergency

Posted Date: March 3rd, 2020

DOI: https://doi.org/10.21203/rs.3.rs-15797/v1

License: () (i) This work is licensed under a Creative Commons Attribution 4.0 International License. Read Full License 


\section{Abstract}

Background: Iran is exposed to a wide variety of natural and man-made hazards. Health care facilities can play a significant role in providing lifesaving measures in the minutes and hours immediately following impact or exposure. The aim of this study was to determine the risk factors threatening the preparedness of health care facilities in disasters and emergencies.

Methods: This cross-sectional study was conducted in Damghan, Semnan province in 2019. The samples consist of all the eleven health care facilities which are located in Damghan County. A developed checklist including 272 questions in four sections; understanding threatening hazards, functional, structural and nonstructural vulnerability of health care facilities was used to collect the data. The data were analyzed using STATA 11 software. The risk factors were determined and prioritized based on mean and total vulnerability score.

Results: The results showed that the health care facilities were exposed to 22 different natural and man-made hazards throughout the county. The overall preparedness of the health care centers was $45 \%$. The average functional, structural, and nonstructural vulnerability was assessed at $40.58 \%, 45.12 \%$, and $50 \%$, respectively.

Conclusion: The findings of this study showed an average preparedness of the health care facilities in the studied area. Conducting the mitigation measures is necessary for reducing the structural and non-structural vulnerability. Disaster educational programs and exercises are recommended among the health staff in order to increase the functional capacity and enhance the preparedness in the HCFs at time of emergencies and disasters.

\section{Background}

Iran is exposed to a wide variety of natural and man-made hazards. This country has been rated as one of nations most at risk from extreme weather and geophysical events according to a study ranked 229 countries on their vulnerability to disasters (1). The statistics demonstrate that in the last 40 years, more than 109,000 people died and 150,000 people injured because of natural disasters in Iran (2). Human-related consequences of disasters and their impact on health service delivery bring health to the top agenda of disaster management (3). Natural disasters, such as earthquakes, volcanic eruptions, floods, tsunamis and hurricanes, and manmade disasters including terrorist attacks, conflict wars, industrial accidents, building collapses and transportation accidents have the potential to result in significant economic loss and human casualties (4). Among these, hospitals and Health Care Facilities (HCFs) play an essential role in providing lifesaving services in urban and rural areas during disasters and emergencies (5). According to statistics, Iran has 25696 HCFs that give healthcare services to $96 \%$ of population around the country (6). So, HCFs have particular importance as they will be central to dealing with a large number of injuries typically associated with large-scale disasters (7). In August 2012, Varzaghan-Ahar twin earthquakes or in November 2017, earthquake in Ezgele, Kermanshah in the northwest and west sides of Iran, the newly-built hospitals and many HCFs were not able to deliver health care services to affected people. The severe damages occurred in their structural components of the hospital and HCFs buildings such as columns, beams and walls during the earthquake $(8,9)$. In such urban 
and rural areas, the majority of residents can just access to HCFs for receiving the governmental services in Iran. Thus, the preparedness of these HCFs against disasters and emergencies should be strengthened, the point that be ignored in most instances. Preparedness capacity includes human resources, facilities, buildings and Standard Operating Procedure (SOP) that would be regularly evaluated and improved (10).

The studies indicated that it is important to have a comprehensive plan in order to measure and promote the preparedness of HCFs against disaster and emergencies $(11,12)$. Also, several researches provided evidence about usefulness and utilization of the health care safety assessment in improving the process of decision making in European countries (13-15). Unfortunately, a majority of local hospitals and HCFs have poorly integrated disaster plans to cope with the harmful consequences of natural and human-induced disasters in Iran (16). Damghan County is located in the Semnan province, the 6th largest province in Iran and situated on the Quaternary plain. Damghan County is exposed to several natural hazards. Four active faults are located in this region that the most dangerous fault namely, Astaneh in the north west of County, has been known as a likely source of 6th deadliest earthquake in the world. On the other hand Damghan is faced with the heavy winds and extreme weather in the most days of a year because it is surrounded by the Alborz mountains range from the north. Also, most of population has low to middle income and access to HCFs for receiving the health care services at time of disasters and emergencies (17). In regard to locate Damghan County on the active faults with high seismic background, exposed to risk of severe hurricanes, accident road, social vulnerability and lack of facilities, it is expected much population refer to HCFs for receiving services at time of disasters and emergencies.

One of the main strategies to achieve the comprehensive disaster management plan is decreasing the vulnerability of hospitals and HCFs by enhancing the functional, structural and non-structural preparedness (18). The aim of this study is to evaluate the preparedness of HCFs in Damghan County to disasters and emergencies.

\section{Methods}

\section{Design and setting}

A field cross-sectional study was conducted at all eleven governmental HCFs in Damghan County under the supervision of Semnan University of Medical Sciences in 2019.

\section{Collecting data instrument}

The research team applied a checklist for collecting data in this study. This checklist was developed based on the Hospital Safety Index (HSI) checklist (19) and the disaster risk assessment checklist in Iranian primary HCFs (20) that both of these tools has been applied in Iran previously (16, 21-23). The checklist using consisted of 272 questions divided into four sections in order to evaluate the preparedness of HFs against disasters and emergencies. The details of each section have been described as the following:

\section{Section A: Understanding threatening hazards}


This section composed of 45 items in 5 elements and refers to the hazards in the surroundings or the events to which the HCFs should be prepared to respond. The assessing hazards divided into geological, hydrometeorological, biological, technological or man-made and societal categories.

\section{Section B: Functional components}

Section B included 173 items in 29 elements and considers the level of the preparedness of HCFs and personnel in response to an emergency or disaster.

\section{Section C: Structural components}

This section designed into 5 elements and items to addresses the structural elements such as Columns, beams, walls and floors to form part of the load-bearing system of the building.

\section{Section D: Non-Structural components}

The last section of the checklist consisted of 49 items in 7 elements and conducts an assessment of the nonstructural elements of HCFs such as windows, doors, stairs, furniture and heating, ventilation, and air conditioning systems. Table 1 presents the elements of each section in using the checklist along with the number of assessed items for each element.

\section{Collecting data and analysis}

The observations in the field were used for completing the checklist in accordance with the ratings established for each item. Each item in section A of the checklist was questioned by two: determine the existence of hazard and if the hazard exists, identify the hazard probability. This process was completed by investigation of maps, backgrounds of incidents, visiting physical location of HCFs and interviewing with the supervisor or experienced staff

The quantitative method was applied for analysis sections B, C and D. We assigned scores of 1 (Low), 2 (Moderate) and 3 (High) to each category, respectively to determine the preparedness level.

For each checklist component (functional, structural and non-structural)equal weight was given to each item.Then, a normalized scoring scheme on a 100-point scale was developed.

HCFs were classified to three preparedness categories according to their normalized total score: low $(<34.0)$, average (34.01-66.0) and high (>66.01) The data was analyzed by STATA software, version 11.

\section{Results}

From March to May 2019, all HCFs that were located in DamghanCounty, assessed their preparedness against disasters and emergencies. Table 1 presents the characteristics of the assessed HCFs.

Table 1 Characteristics of HCFs understudy, Damghan County, 2019 


\begin{tabular}{|l|c|c|c|l|l|l|c|}
\hline HCFs & Type & Age & Material construction & HCFs & Type & Age & Material construction \\
\hline HCF 1 & Rural & 40 & Brick & HCF 7 & Urban & 16 & Concrete \\
\hline HCF 2 & Rural & 40 & Brick & HCF 8 & Rural & 40 & Brick \\
\hline HCF 3 & Urban & 29 & Brick & HCF 9 & Urban & 40 & Brick \\
\hline HCF 4 & Urban & 40 & Concrete & HCF 10 & Rural & 40 & Concrete \\
\hline HCF 5 & Rural & 3 & Iron & HCF 11 & Rural & 39 & Brick \\
\hline HCF 6 & Rural & 40 & Concrete & & & & \\
\hline
\end{tabular}

The result of literature review and expert panel session about the most important and threatening natural and man-made hazards and their probability have been indicated in the following Table.

Table 2 Recognition and occurrence probability of threatening hazards in HCFs, Damghan County, 2019 


\begin{tabular}{|c|c|c|c|c|c|c|c|}
\hline \multirow[t]{2}{*}{ Hazard Type } & \multirow{2}{*}{$\begin{array}{r}\text { Probability } \\
\text { Hazards }\end{array}$} & \multicolumn{3}{|c|}{ Urban HCFs } & \multicolumn{3}{|c|}{ Rural HCFs } \\
\hline & & High & Moderate & Low & High & Moderate & Low \\
\hline \multirow[t]{3}{*}{ Geologic } & Earthquake & $100 \%$ & $0 \%$ & $0 \%$ & $100 \%$ & $0 \%$ & $0 \%$ \\
\hline & $\begin{array}{r}\text { Landslides (following } \\
\text { earthquake) }\end{array}$ & $0 \%$ & $0 \%$ & $100 \%$ & $43 \%$ & $0 \%$ & $57 \%$ \\
\hline & Subsidence & $0 \%$ & $0 \%$ & $100 \%$ & $57 \%$ & $0 \%$ & $43 \%$ \\
\hline \multirow{9}{*}{$\begin{array}{c}\text { Hydro- } \\
\text { Metrologic }\end{array}$} & Tornado & $0 \%$ & $0 \%$ & $100 \%$ & $57 \%$ & $0 \%$ & $43 \%$ \\
\hline & Hurricane & $100 \%$ & $0 \%$ & $0 \%$ & $100 \%$ & $0 \%$ & $0 \%$ \\
\hline & Heavy rain & $0 \%$ & $100 \%$ & $0 \%$ & $43 \%$ & $57 \%$ & $0 \%$ \\
\hline & Flash flood & $0 \%$ & $0 \%$ & $100 \%$ & $71 \%$ & $0 \%$ & $29 \%$ \\
\hline & $\begin{array}{r}\text { Landslides (following } \\
\text { heavy rain/flood) }\end{array}$ & $0 \%$ & $0 \%$ & $100 \%$ & $43 \%$ & $0 \%$ & $57 \%$ \\
\hline & Extreme temperature & $0 \%$ & $100 \%$ & $0 \%$ & $43 \%$ & $57 \%$ & $0 \%$ \\
\hline & Dust storm & $0 \%$ & $100 \%$ & $0 \%$ & $14 \%$ & $86 \%$ & $0 \%$ \\
\hline & Blizzard & $0 \%$ & $0 \%$ & $100 \%$ & $43 \%$ & $0 \%$ & $57 \%$ \\
\hline & Heavy winds & $100 \%$ & $0 \%$ & $0 \%$ & $100 \%$ & $0 \%$ & $0 \%$ \\
\hline \multirow{7}{*}{$\frac{\text { Societal }}{\text { Biologic }}$} & Displaced population & $0 \%$ & $0 \%$ & $0 \%$ & $0 \%$ & $29 \%$ & $71 \%$ \\
\hline & $\begin{array}{l}\text { Security threat } \\
\text { staffHFs / to }\end{array}$ & $0 \%$ & $0 \%$ & $0 \%$ & $0 \%$ & $0 \%$ & $0 \%$ \\
\hline & Kidnapping & $0 \%$ & $25 \%$ & $75 \%$ & $0 \%$ & $0 \%$ & $100 \%$ \\
\hline & Cyber threats & $0 \%$ & $100 \%$ & $0 \%$ & $0 \%$ & $100 \%$ & $0 \%$ \\
\hline & Epidemics & $0 \%$ & $0 \%$ & $100 \%$ & $57 \%$ & $0 \%$ & $43 \%$ \\
\hline & Vermin attacks & $0 \%$ & $0 \%$ & $100 \%$ & $0 \%$ & $100 \%$ & $0 \%$ \\
\hline & Wild animal attacks & $0 \%$ & $0 \%$ & $100 \%$ & $0 \%$ & $100 \%$ & $0 \%$ \\
\hline \multirow{8}{*}{$\begin{array}{l}\text { Technologic/ } \\
\text { man-made }\end{array}$} & Gas explosion & $0 \%$ & $0 \%$ & $100 \%$ & $0 \%$ & $0 \%$ & $100 \%$ \\
\hline & Fires & $0 \%$ & $100 \%$ & $0 \%$ & $0 \%$ & $100 \%$ & $0 \%$ \\
\hline & Harmful agents release & $0 \%$ & $50 \%$ & $50 \%$ & $0 \%$ & $14 \%$ & $86 \%$ \\
\hline & Power outage & $0 \%$ & $100 \%$ & $0 \%$ & $0 \%$ & $100 \%$ & $0 \%$ \\
\hline & Water outage & $0 \%$ & $100 \%$ & $0 \%$ & $0 \%$ & $100 \%$ & $0 \%$ \\
\hline & evacuationHFCImmediate & $0 \%$ & $0 \%$ & $100 \%$ & $0 \%$ & $0 \%$ & $100 \%$ \\
\hline & Mass casualty incidents & $0 \%$ & $0 \%$ & $100 \%$ & $0 \%$ & $0 \%$ & $100 \%$ \\
\hline & Burglary & $0 \%$ & $25 \%$ & $75 \%$ & $0 \%$ & $0 \%$ & $100 \%$ \\
\hline
\end{tabular}

In general, all the HCFs are at high risk of earthquake among the geologic hazards. The probability of landslides following an earthquake is also estimated high. Among the hydrometrological hazards, $100 \%$ of HCFs are at high risk of hurricane. The occurrence probability of flash floods is assessed at high level in $45 \%$ of HCFs. The overall HCFs are at moderate risk level of cyber-attack in comparison to other societal hazards.

Some evidences indicate that endemic diseases such as Cutaneous Leishmaniasis have the high potential to spread quickly and convert to epidemics in the area understudy, particularly in the $42.8 \%$ of rural HCFs. Also, the occurrence of water-food borne diseases is more probable in the rural areas than urban areas that indicate $64 \%$ of HCFs are at higher risk. The risk of vermin 
attacks can be classified at moderate level in $64 \%$ of rural areas. Additionally, man-made hazards such as fire, chemical threats, power outage and water outage have been allocated the moderate risk level to themselves in HCFs understudy.

Table 3 Descriptive results of preparedness components in urban and rural HCFs 


\begin{tabular}{|c|c|c|c|c|c|c|}
\hline \multirow[t]{3}{*}{ onent } & \multirow{3}{*}{$\begin{array}{l}\text { Element, no. of } \\
\text { questions } \\
\text { (expected score } \\
\text { range) }\end{array}$} & \multicolumn{2}{|c|}{ HCF } & \multirow{3}{*}{$\begin{array}{c}\text { Element, no. of } \\
\text { questions } \\
\text { (expected score range) }\end{array}$} & \multicolumn{2}{|c|}{ HCF } \\
\hline & & Urban & Rural & & Urban & Rural \\
\hline & & $\begin{array}{l}\text { Mean } \\
(\mathrm{SD})\end{array}$ & $\begin{array}{c}\text { Mean } \\
\text { (SD) }\end{array}$ & & $\begin{array}{c}\text { Mean } \\
\text { (SD) }\end{array}$ & $\begin{array}{l}\text { Mean } \\
\text { (SD) }\end{array}$ \\
\hline \multirow[t]{14}{*}{$\overline{\text { ional }}$} & $\begin{array}{r}\text { Organizing and } \\
\text { structure, } 4 \text { (5-7) }\end{array}$ & $5.5(1)$ & $\begin{array}{c}6.33 \\
(1)\end{array}$ & $\begin{array}{r}\text { Assistance and } \\
\text { volunteers management, } \\
4(0-8)\end{array}$ & $8(0)$ & $8(0)$ \\
\hline & $\begin{array}{r}\text { Preparedness plan, } 4 \\
(5-11)\end{array}$ & $\begin{array}{l}10.25 \\
(0.5)\end{array}$ & $\begin{array}{c}6.66 \\
(2.58)\end{array}$ & Finance affairs, $2(0-2)$ & $2(0)$ & $2(0)$ \\
\hline & $\begin{array}{r}\text { Risk assessment, } 8 \\
(13-17) \\
\end{array}$ & $\begin{array}{c}15.5 \\
(0.57) \\
\end{array}$ & $\begin{array}{l}14.83 \\
(1.47) \\
\end{array}$ & $\begin{array}{r}\text { Safety and security, } 12 \\
(0-18) \\
\end{array}$ & $18(0)$ & $18(0)$ \\
\hline & $\begin{array}{r}\text { Risk mitigation } \\
\text { measures, } 3(5-6)\end{array}$ & $6(0)$ & $\begin{array}{c}5.33 \\
(0.51)\end{array}$ & $\begin{array}{r}\text { Informing to } \\
\text { stakeholders, } 2(2-3)\end{array}$ & $\begin{array}{l}2.25 \\
(0.5)\end{array}$ & $3(0)$ \\
\hline & $\begin{array}{r}\text { Insurance coverage, } 3 \\
(0-3) \\
\end{array}$ & $3(0)$ & $3(0)$ & $\begin{array}{r}\text { Rapid response team, } 3 \\
(3-4) \\
\end{array}$ & $\begin{array}{l}3.75 \\
(0.5)\end{array}$ & $\begin{array}{l}3.83 \\
(0.4) \\
\end{array}$ \\
\hline & $\begin{array}{r}\text { Coordination, } 11 \text { (15- } \\
16)\end{array}$ & $16(0)$ & $\begin{array}{c}15.3 \\
(0.51)\end{array}$ & $\begin{array}{l}\text { Fire extinguishing, } 3 \text { (7- } \\
\text { 8) }\end{array}$ & $\begin{array}{l}7.25 \\
(0.5)\end{array}$ & $8(0)$ \\
\hline & $\begin{array}{r}\text { Incident command } \\
\text { system, } 5 \text { (6-9) }\end{array}$ & $\begin{array}{l}7.75 \\
(1.25)\end{array}$ & $\begin{array}{c}8 \\
(0.63)\end{array}$ & Exercise, 12 (15-21) & $\begin{array}{l}17.5 \\
(2.64)\end{array}$ & $\begin{array}{c}18.5 \\
(0.83)\end{array}$ \\
\hline & $\begin{array}{r}\text { Communication and } \\
\text { early warning, } \\
7(0-9)\end{array}$ & $9(0)$ & $9(0)$ & Recovery, 5 (0-5) & $5(0)$ & $5(0)$ \\
\hline & Evacuation, 5 (7-9) & $\begin{array}{c}8 \\
(0.81)\end{array}$ & $\begin{array}{c}7.83 \\
(9.40)\end{array}$ & $\begin{array}{r}\text { Environmental health } \\
\text { office, } \\
8(0-11)\end{array}$ & $11(0)$ & $11(0)$ \\
\hline & $\begin{array}{r}\text { Need assessment, } 2 \\
(3-4)\end{array}$ & $\begin{array}{l}3.25 \\
(0.5)\end{array}$ & $\begin{array}{c}3.5 \\
(0.45)\end{array}$ & $\begin{array}{r}\text { Communicable disease } \\
\text { center, } \\
10(0-12)\end{array}$ & $12(0)$ & $12(0)$ \\
\hline & Logistic, 10 (9-12) & $\begin{array}{c}9.5 \\
(0.57)\end{array}$ & $\begin{array}{l}10.16 \\
(0.98)\end{array}$ & $\begin{array}{r}\text { Non-communicable } \\
\text { disease center, } 9(0-9)\end{array}$ & $9(0)$ & $9(0)$ \\
\hline & $\begin{array}{r}\text { Mental health of staff } \\
\text { and their families, } 2 \\
(0-2)\end{array}$ & $2(0)$ & $2(0)$ & $\begin{array}{r}\text { Reproductively health } \\
\text { office, } \\
13 \text { (0-13) }\end{array}$ & $13(0)$ & $13(0)$ \\
\hline & $\begin{array}{r}\text { Service continuation, } \\
5(0-7)\end{array}$ & $7(0)$ & $7(0)$ & $\begin{array}{r}\text { Nutrition office, } 10(0- \\
10)\end{array}$ & $10(0)$ & $10(0)$ \\
\hline & $\begin{array}{r}\text { Transportation, } 2(2- \\
3)\end{array}$ & $\begin{array}{l}2.25 \\
(0.5)\end{array}$ & $3(0)$ & $\begin{array}{r}\text { Societal-mental office, } 7 \\
(0-11)\end{array}$ & $11(0)$ & $11(0)$ \\
\hline \multirow[t]{4}{*}{$\begin{array}{l}\text { jn- } \\
\text { stural }\end{array}$} & $\begin{array}{r}\text { Electrical System, } 8 \\
(0-24) \\
\end{array}$ & $12(0)$ & $12(0)$ & Medical gases, $4(0-12)$ & $8(0)$ & $\begin{array}{c}7.14 \\
(0.38) \\
\end{array}$ \\
\hline & $\begin{array}{l}\text { Communication } \\
\text { system, } 5(0-15)\end{array}$ & $8(0)$ & $8(0)$ & $\begin{array}{r}\text { Heating, ventilation, and } \\
\text { air conditioning systems, } \\
3(0-9)\end{array}$ & $5(0)$ & $5(0)$ \\
\hline & $\begin{array}{r}\text { Water supply, } 4 \text { (0- } \\
12)\end{array}$ & $5(0)$ & $5(0)$ & $\begin{array}{l}\text { Furnishing and office } \\
\text { equipment, } 21(0-63)\end{array}$ & $\begin{array}{c}45 \\
(0.81)\end{array}$ & $45(0)$ \\
\hline & $\begin{array}{r}\text { Fuel storage (Gas, } \\
\text { Petrol, Gasoline), } 3 \\
(0-9)\end{array}$ & $4(0)$ & $4(0)$ & & & \\
\hline$\overline{\text { tural }}$ & $\begin{array}{r}\text { Structural elements, } 4 \\
(0-12)\end{array}$ & $4(0)$ & $4(0)$ & & & \\
\hline
\end{tabular}


According to Table 3, organizing and structure (), needs assessment (), informing to stakeholders (), transportation ( and exercise (scored below the expected average among the elements of functional preparedness in urban HFCs. These elements in rural HCFs were included of preparedness plan (), coordination (), evacuation (). The mean score of disaster logistic factor was less than the expected average in both urban and rural HCFs. Additionally, the situation of water supply and fuel storage scored 5 that were less than 6 as the expected average among the assessment of non-structural elements. The similar result was obtained in the assessment of structural elements and the obtained mean score()were less than expected average in both urban and rural HCFs.

The overall disaster preparedness level in HCFs understudy was equal to $45.8 \%$. According to the obtained results for measuring preparedness, six HCFs (58\%) were classified as low preparedness, two HCFs (18\%) were categorized as moderate preparedness and the rest (24\%) had high preparedness to emergencies and disasters (Fig 1.).

\section{Discussion}

The present study showed that from among the geological hazards, earthquake is the most likely to occur in Damghan County and healthcare centers are most highly affected by this natural disaster. Literature review showed that there are four active faults passing underneath Damghan. One of these faults, called Astaneh, on the northwest of Damghan, accounted for the sixth largest earthquake in the world, measuring $7.6 \mathrm{M}$ and killing 200.000 (17). In previous studies which investigated the natural disasters in Iran, due to numerous faults and high seismicity in the country, earthquake is considered as the biggest hazard in the country $(2,24)$. Additionally, in the present study, the probability of landslides following an earthquake is also higher in the mountaineer regions of three rural HCFs. Among the weather hazards, storms and floods were the most likely to occur, which could be due to the geography of the region, the town's confinement to the Alborz mountains to the north, difference in the elevation of the various districts, and the land slope (25). Also, the occurrence probability of blizzard and heavy winds are predicted higher in the mountaineer areas of county in comparison to plain regions that include $72.7 \%$ of assessed HCFs. Among man-made disasters, fires are very likely due to non-compliance with safety requirements, lack of fire prevention systems such as automatic fire detecting or extinguishing systems. Cyber-attacks are also highly likely due to the lack of well-established computer infrastructures in the healthcare centers. In addition, Damghan is a biologically vulnerable area in terms of Cutaneous Leishmaniasis due to being home to the major resources of the disease such as rodents (26). Also, the evidence indicates an epidemic occurrence of Cutaneous Leishmaniasis in rural areas of Damghan in 2009, where on average more than 100 new cutaneous cases occur annually (27). Literature reviews show that the incidence of the disease is higher in the plain rural areas than urban areas (28), where $43 \%$ of health centers studied was located in such these areas in the present study. In addition, in some cases the inadequate environmental health and potential problems in water chlorination in these areas have been associated with outbreaks of water and food-borne diseases (29).

The results of this study showed that the level of total preparedness in the evaluated HCFs is about $46 \%$. A similar study in Kermanshah also showed that this figure is about $35 \%$ in existing HCFs (30), while similar surveys on preparedness in Tabriz and Qazvin hospitals indicated that these hospitals are only moderately prepared for the disasters $(31,32)$. The difference in readiness between HCFs and hospitals in Iran can be 
attributed to their success in attracting more funds. The rural population accounts for more than $26 \%$ of the total population of the country and the rural residents could access to HCFs only for the necessary health care services. In general, the unequal delivery and access to medical services are accompanied with disasters. In recent years, disasters have posed greater threats to communities lacking the enough resources and timely access to healthcare services by the disaster-affected people (33). Currently, Iran has developed its capacities to reduce disaster risk and increase preparedness at the international, national and local levels, but due to limited resources and some inappropriate practices in the past, it is still insufficient $(34,35)$.

An important finding of this study is that all factors evaluated in the structural section of urban and rural health centers have a lower score than the expected average. In case such conditions persist and without retrofitting of existing building, seismic vulnerability of these HCFs increases (36). In case of earthquake occurrence, they are highly likely to collapse, leading to disruption of health care services, exacerbation of the injuries and higher mortality rate of vulnerable groups such as pregnant women, children and the elderly. This situation is similar to what happened in the Bam earthquake, 2003, Iran that $90 \%$ of HCFs damaged or in Sumatra earthquake in western Indonesia in 2009, where eight out of the 9 primary health care centers were collapsed by the earthquake $(18,37)$. Therefore, intactness of HCFs during disasters is crucial to responding to health needs and preventing further mortality. In case of functional preparedness, the most effective factors in the reduction of the preparedness level against disasters and emergencies in HCFs are: organizing and structure, coordination, exercise, informing stakeholders, risk reduction plans including risk assessment and emergency evacuation and logistic. Similar results were obtained in the study of disaster preparedness of HCFs in Kermanshah. Insufficient water and electricity resources were other factors in the reduction of nonstructural preparedness in urban and rural HCFs in this study. According to the preparedness principal of hospitals and HCFs for disasters, it is recommended that these critical centers are provided with adequate water and electricity resources up to 72 hours after the disaster, so that during the time, the organization is able to be self-sufficient and continue operating and delivering health care services to disaster-affected people in an independent manner $(38,39)$.

Regarding to the moderate percentage (47.5\%) of HCFs preparedness, it is necessary to enhance the overall disaster preparedness level due to functional, structural and non-structural assessments. The measures for promoting preparedness in HCFs should focus on structural, functional and non-structural preparedness, respectively. Also, planning and implementing the disaster management programs are essential in increasing the overall hospital disaster preparedness level (40). As the World Health Organization (WHO) worked seriously on disaster preparedness programs in 2008-2009 as part of a global campaign $(16,41)$, there may be a need to attract the support of international organizations such as WHO and UNISDR to increase the preparedness level of HCFs to deal with these disasters.

\section{Conclusions}

According to the results of this study, it is expected that the government will allocate sufficient funds to do the measures for promoting the overall preparedness level of HCFs to disasters and emergencies.

Constructing new buildings for HCFs in accordance with seismic safety codes or retrofitting the existing buildings increase the structural preparedness level. In addition, continuous training, conducting periodic 
exercises and providing the enough power and water back up for 72 hours after disasters are another suggestion for improving the functional and non-structural preparedness, respectively.

\section{Declarations}

\section{Authors' contributions}

FF and BP conceptualized and designed the study and AM collected data. AH and FF analyzed data and FF and BP wrote and edited the manuscript. All authors read and approved the final manuscript.

\section{Funding}

The authors received no specific funding for this study.

\section{Availability of data and materials}

The data supporting the conclusions in this article are available in the additional files. Data supporting study findings are available upon request.

\section{Ethics approval and consent to participate}

The Ethics Committee of Semnan University of Medical Sciences approved this study (IR.SEMUMS.REC.1397.108).

\section{Consent for publication}

Not applicable.

\section{Competing interests}

The authors declare that they have no competing interests.

\section{Abbreviations}

HCFs: Health Care Facilities

HSI: Hospital Safety Index

WHO: World Health Organization

UNISDR: United Nations International Strategy for Disaster Reduction

\section{References}

1. McGeown J. Bangladesh, Indonesia and Iran top natural disaster ranking - France, Italy, USA at "high risk". 2010. 
2. UNISDR. National report of the Islamic Republic of Iran on disaster reduction. Geneva; 2005.

3. Ardalan A, Masoomi G, Goya M, Ghaffari M, Miadfar J, Sarvar M, et al. Disaster Health Management: Iran's Progress and Challenges. Iran J Public Health. 2009;38(1):93-7.

4. Yi P, George SK, Paul JA, Lin L. Hospital capacity planning for disaster emergency management. SocioEconomic Planning Sciences. 2010;44(3):151-60.

5. Top M, Gider Ö, Tas Y. An Investigation of Hospital Disaster Preparedness in Turkey. Journal of Homeland Security and Emergency Management. 2010.

6. Damari B, Riazi-Isfahani S. Evaluating the women health volunteers program in Iran- a quarter century experience (1992-2016). Arch Iran Med. 21(12):566-71.

7. Achour N, Price A. Resilience strategies of healthcare facilities: present and future. International Journal of Disaster Resilience in the Built Environment. 2010;1(3):264-76.

8. Pouraghaei M, Jannati A, Moharamzadeh P, Ghaffarzad A, Far MH, Babaie J. Challenges of Hospital Response to the Twin Earthquakes of August 21, 2012, in East Azerbaijan, Iran. Disaster Medicine and Public Health Preparedness. 2017;11(4):422-30.

9. Khankeh H, Kolivand PH, Beyrami Jam M, Rajabi E. Kermanshah Health Care Services: A Lesson Learned From Iran's Recent Earthquake. Health in Emergencies and Disasters Quarterly. 2018;3(4):221-33.

10. Chartoff S, Roman P. Disaster Planning: StatPearls Publishing;2018.

11. Drenkard K, Rigotti G, Hanfling D, Fahlgren TL, LaFrancois G. Healthcare system disaster preparedness, part 1: readiness planning. The Journal of nursing administration. 2002; 32(9):461-9.

12. Heidaranlu E, Ebadi A, Khankeh HR, Ardalan A. Hospital Disaster Preparedness Tools: a Systematic Review. PLoS currents. 2015; 14;7.

13. Ingrassia PL, Mangini M, Azzaretto M, Ciaramitaro I, Costa L, Burkle FM, Jr., et al. Hospital Disaster Preparedness in Italy: a preliminary study utilizing the World Health Organization Hospital Emergency Response Evaluation Toolkit. Minerva anestesiologica. 2016;82(12):1259-66.

14. Rockenschaub G, Harbou KV. Disaster resilient hospitals: an essential for all-hazards emergency preparedness. World hospitals and health services : the official journal of the International Hospital Federation. 2013;49(4):28-30.

15. Radović V, Vitale K, Tchounwou P. Health facilities safety in natural disasters: experiences and challenges from South East Europe. International Journal of Environmental Research and Public Health. 2012;9(5):1677-86.

16. Ardalan A, Kandi Keleh M, Saberinia A, Khorasani-Zavareh D, Khankeh H, Miadfar J, et al. 2015 Estimation of Hospitals Safety from Disasters in I.R.Iran: The Results from the Assessment of 421 Hospitals. PloS One. 2016;11(9).

17. Ramzi HR, Jalili M. Seismotectonic and Seismicity Analysis of the Damghan Region, Iran. Journal Geological Siciety of India. 2015;85:619-26.

18. Fuady A, Pakasi T, Mansyur M. Primary Health Centre disaster preparedness after the earthquake in Padang Pariaman, West Sumatra, Indonesia. BMC Res Notes. 2011;4:81.

19. (PAHO) P-AHO. Hospital Safety Index: Guide for evaluators. Second ed: World Health Organization (WHO) and Pan-American Health Organization (PAHO);2015. 
20. Ardalan A, Shariati M, Kandi M, Ghotbabadi F, al. e. Disaster risk assessment in Primary health care facilities. Tehran: Ministry of Health and Medical education;2011.

21. Ardalan A, Kandi M, Talebian MT, Khankeh H, Masoumi G, Mohammadi R, et al. Hospitals safety from disasters in IR iran: the results from assessment of 224 hospitals. PLoS currents. 2014;6.

22. Ardalan A, Mowafi H, Malekafzali Ardakani H, Abolhasanai F, Zanganeh A-M, Safizadeh H, et al. Effectiveness of a Primary Health Care Program on Urban and Rural Community Disaster Preparedness, Islamic Republic of Iran: A Community Intervention Trial. Disaster medicine and public health preparedness. 2013;7(5):481-90.

23. Djalali A, Ardalan A, Ohlen G, Ingrassia PL, Corte FD, Castren M, et al. Nonstructural Safety of Hospitals for Disasters: A Comparison Between Two Capital Cities. Disaster medicine and public health preparedness. 2014;8(2):179-84.

24. Peyravi M, Marzaleh M, Khorram-Manesh A. An Overview of the Strengths and Challenges Related to Health on the First 10 Days after the Large Earthquake in the West of Iran, 2017. . Iranian Journal of Public Health. 2019;48(5):963-70.

25. Mohammadi S, Nokandeh Z, Khorsandi A, Sanei Dehkordi AR. Epidemiology of cutaneous leishmaniasis in Damghan district. J Mil Med. 2010;12(3):131-5.

26. Pourmohammadi B, Mohammadi-Azni S. Molecular Detection of Leishmania major in Hemiechinus auritus, A Potential Reservoir of Zoonotic Cutaneous Leishmaniasis in Damghan, Iran. . J Arthropod Borne Dis. 2019;13(3):334-43.

27. Pourmohammadi B, Mohammadi-Azni S, Kalantari M. Natural infection of Nesokia indica with Leishmania major and Leishmania infantum parasites in Damghan city, Northern Iran. Acta tropica. 2017 Jun;170:1349.

28. Almasi A, Shirdare MR, Emadi J, Esfandiari M, Pourmohammadi B, Hisseini SH. Epidemiological study of Cutaneous Leishmaniasis in Marvdasht, Fars Province, Iran. Quarterly Journal of North Khorasan University of Medical Sciences 2012;3(4(10)):15-23.

29. Angoua ELE, Dongo K, Templeton MR, Zinsstag J, Bonfoh B. Barriers to access improved water and sanitation in poor peri-urban settlements of Abidjan, Cote d'Ivoire. PloS one. 2018;13(8).

30. Dargahi A, Farrokhi M, Poursadeghiyan M, Ahagh M, Karami A. Evaluation of Functional Preparedness and Non Structural Safety of Different Health Units of Kermanshah University of Medical Sciences in Coping With Natural Disasters. Health in Emergencies and Disasters Quarterly. 2017;2(4):201-6.

31. Vali L, Masoud A, JabariBeyrami H, Yaghobian B. Readiness of hospitals affiliated with Tabriz University of Medical Sciences to Face Disasters. Journal of Health and Development. 2014;3:62-70.

32. Khazaei M Y, Jamaly Z, Safi K M, Asgary J, Khoshghadam M, Farzam S, et al. How is training hospitals of Qazvin preparedness against disaster in 2015? Ann Trop Med Public Health. 2017;10:1205-9.

33. Davis J, Wilson S, Brock-Martin A, Glover S, Svendsen E. The impact of disasters on populations with health and health care disparities. Disaster medicine and public health preparedness. 2010;4(1):30-8.

34. Owens M, Buffington C, Frost M, Waldner R. The South Dakota Model: Health Care Professions Student Disaster Preparedness and Deployment Training. Disaster medicine and public health preparedness. 2017;11(6):735-40. 
35. (UNISDR). UNISfDR. Global Assessment Report on Disaster Reduction. 2009. Geneva; 2009.

36. Muñoz A, Quiun D, Tinman M, editors. Repair and seismic retrofitting of hospital and school buildings in Peru. Proceedings of the Thirteenth World Conference on Earthquake Engineering; 2004; Vancouver, Canada.

37. Kalantar MH, Sagafinia M, Ebrahimi A, Shams E. Major earthquakes of the past decade (2000-2010): a comparative review of various aspects of management. . Trauma Mon. 2012;17(1):219-29.

38. Hospital Safety Index; Guide for Evaluators. Washington DC: Pan American Health Organization; 2008.

39. Ciottone G, Biddinger P, Darling R, Fares S, Keim M, Molloy M, et al. Ciottone's Disaster Medicine 2nd ed: Elsevier; 2015.

40. Pengfei Y, Santhosh K G, Jomon A P, Li L. Hospital capacity planning for disaster emergency management. Socio-Economic Planning Sciences. 2010;44(3):151-60.

41. Rajaei-Ghafouri R, Mirzahosseini S, Pouraghaei M. Are our hospitals safe against disasters? An evaluation of hospital safety index in Tabriz, Iran. J Anal Res Clin Med. 2018;6(3):139-44.

\section{Figures}

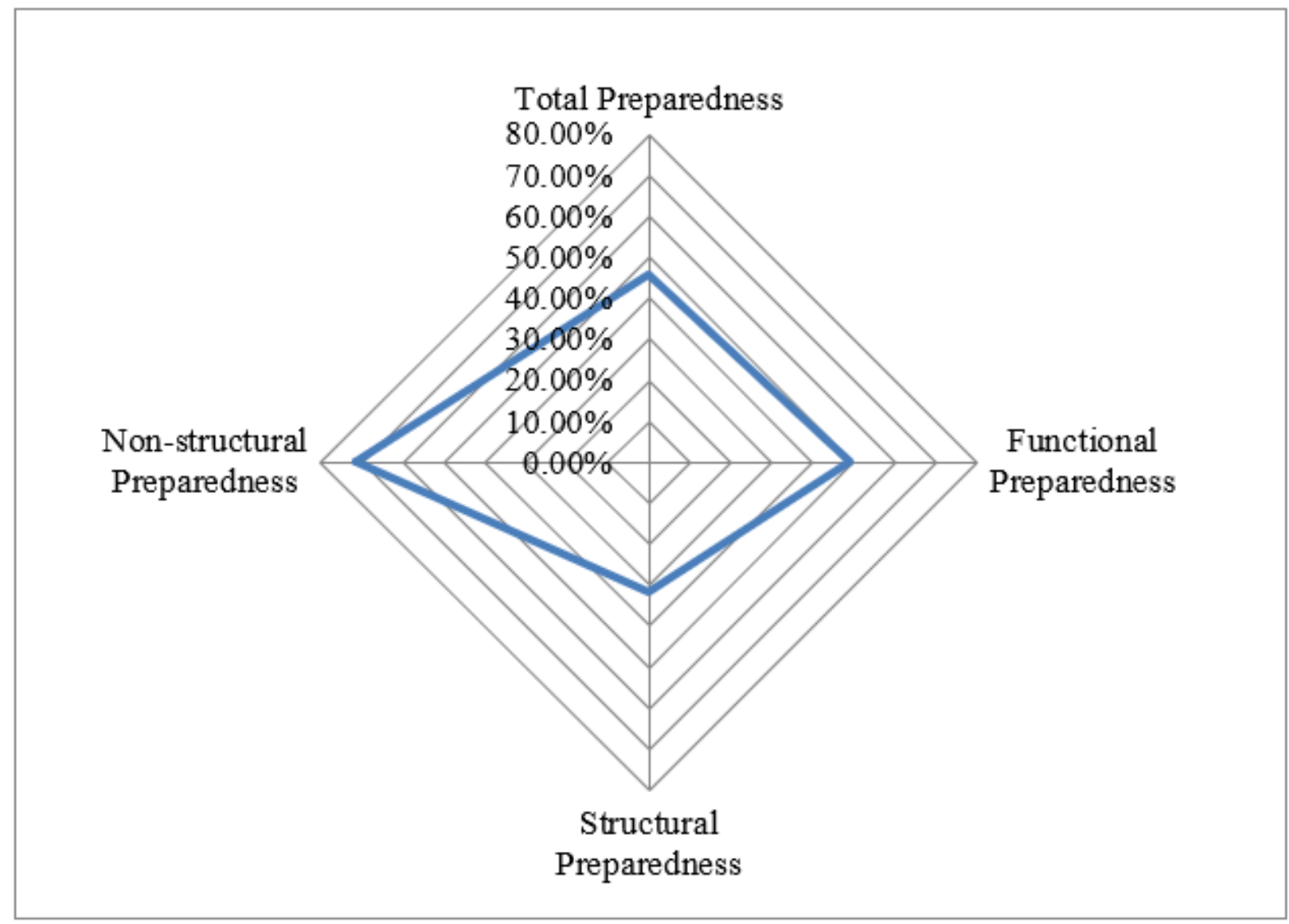

\section{Figure 1}

Total preparedness assessment of HCFs to emergencies and disasters in Damghan County, 2019 